\title{
Public Behaviour on Cash Waqf: Evidence from Indonesia
}

\author{
${ }^{1}$ Banu M Haidlir, ${ }^{2}$ Bambang S Laksmono, ${ }^{3}$ Rahmatina A Kasri, ${ }^{4}$ Azizon, ${ }^{5}{ }^{\bowtie}$ Djoni Hartono \\ 1,2,3,4,5Faculty of Economics and Business, University of Indonesia \\ Permalink/DOI: https://doi.org/10.15294/jejak.v14i2.32032
}

Received: May 2021; Accepted: July 2021; Published: September 2021

\begin{abstract}
Despite the potential governmental agenda towards cash waqf, this area has been givessn limited attention in academic literature with special regards to the supply side. Therefore, this study aims to investigate the factors influencing the public intention in endowing cash waqf by utilizing an extended theory of planned behaviors (TPB); in which religiosity, knowledge, and trust variables are added. Primary data from 685 respondents in Indonesia are analyzed using structural equation modeling (SEM). The result showed that the intention to endow cash waqf is positively affected by all of the TPB variables (attitude, subjective norms, and perceived behavioral control) and other extended variables. The findings suggest an optimization in waqf fund collection and waqf fund management. For waqf collection, it is important to improve public literacy and the quality and quantity of supporting facilities and systems. Meanwhile, institutional management should be strengthened for waqf management.
\end{abstract}

Key words : Cash Waqf, Public behaviors, Theory of planned behaviors, Islamic Social Finance, Charity

How to Cite: Haidlir, B., Laksmono, B., Kasri, R., Azizon, A., \& Hartono, D. (2021). Public Behaviour on Cash Waqf: Evidence from Indonesia. JEJAK: Jurnal Ekonomi dan Kebijakan, $14(2)$. doi:https://doi.org/10.15294/jejak.v14i2.32032 


\section{INTRODUCTION}

It covers background of study, motivation in writing the paper, problems, brief literature review that relates directly to research or previous findings that need to be developed, and ended with a paragraph of research purposes. It should be written in paragraphs.

The current positive growth of Islamic economics and finance has impacted the development of Islamic social finance, especially in terms of Islamic charitable giving. Besides zakah, which is relatively more popular, there is also waqf which has been prioritized by the government of many Muslim countries including Indonesia as the largest among them. Compared to zakah, however, the legal implementation of waqf is relatively delayed as it gets less attention from the public and policymakers. Fortunately, this attention and encouragement have drastically shifted especially for the cash waqf. The cash waqf has been a national movement in Indonesia since early 2021.

As a whole, waqf refers to certain possessions held and/or saved for the confined benefit of any philanthropy use while its literal definition is to stop, to prohibit and to confine. (Mahamood, 2006; and Wahbah, 1985). Yusof, et al (2017) and Shukor, et al (2018) highlighted that waqf is everlasting, which means it can neither be returned nor refunded, so any disposition is forbidden. Waqf could also be used in funding the development of ummah. (Kahf, 1999), utilized for poverty alleviation (Sadeq, 2002), served for social objective and hence waqf could support economic growth through national development plan (Mohamed Yusof, et al., 2017).

Initially, there are two types of waqf implemented in the society; immovable property ('aqar) such as land and building, and movable property (manqul) such as Holy Quran, cash, and books (Ab Rahman, 2009). In the context of Indonesia, based on the report of the Indonesian Waqf Board (BWI), waqf in Indonesia is dominated by immovable properties, mostly land. The cash waqf endowed during 2011-2018 was only around $0.14 \%$ of its potential number. Whereas, in term of a movable asset, the cash waqf is more flexible and simpler because it can provide liquidity and option which can be used in any variation of activity and investment in the market (Kuran, 2001). Cash waqf comes as a great solution to the liquidity problem faced by many mutawallis (the person who takes over the management of waqf, which later stated as 'awqaf institution') in developing waqf properties and assets. Besides, cash waqf has the least burden and procedure in that it does not need complex documentations for the asset transfer and the participation rate of this type of waqf is higher since waqifs can give as much as they wished (Mahamood, 2011; Osman, et al., 2016). In terms of function, cash waqf serves as a flexible financial tool for the Muslim Ummah since the allotment of the fund and/ or the return obtained from cash waqf can be channeled into a variative public project (Cizacka, 2000). Hence, cash waqf is believed to open wide opportunities for Muslims to be involved in this practice. It is also a potential source of funds in the Islamic economy.

The mismatch between the previous public attractiveness and the great potential of cash waqf is one of the reasons encouraging the Indonesian government to create the National Movement of Cash Waqf (GNWU, which stands for Gerakan Nasional Wakaf Uang). GNWU was launched to increase the role of waqf in the economy and public welfare as well as improving the management of waqf in Indonesia. The noteworthy target of this movement is increasing the quantity of cash waqf endowed. Since this is a relatively new movement, its development is still in the early 
stage and the success of this movement is also questionable. However, it could be taken that the main criteria of the movement's success are theoretically its effectiveness in encouraging people to endow cash waqf. It is crucial to explore the public (society) behavior towards cash waqf to determine whether or not this program is effective in increasing cash waqf endowment in Indonesia. This behavior could be a reference for implementing an effective strategy/ program to optimize the GNWU and other agenda related to cash waqf endowment.

However, there is only a small number of empirical studies which tried to discuss society's behavior of cash waqf, especially in the Indonesian context. Most behavioral studies related to cash waqf were conducted in Malaysia (Shukor, et al., 2018; Said \& Saad, 2016; Zain, et al., 2019; Azizi \& Sabri, 2019; Osman \& Muhammad 2017). The few studies of waqf in Indonesia are also dominated by the management context. The study focusing on the aspect of collection (fund supply) is limited. One of the related studies was conducted by Indahsari, et al (2014), exploring the determinants of Muslim's behavior in accomplishing waqf through amil institution in Madura, Indonesia. However, Indahsari, et al (2014) focused not only on waqf but also on other instruments of Islamic social finance such as zakah, infaq, and sadaqah (ZISWA). They found that the main determinant of Muslim's behavior in accomplishing ZISWA through amil institutions is the external factor related to Muslim's trust in amil institutions.

Based on this perspective, the present study specifically aims to explore the factors influencing social behavior and intention towards cash waqf in Indonesia. Following the previous study related to this topic (Shukor, et al., 2018; Osman, et al., 2016; Johari, et al., 2015; and Indahsari, et al., 2014;
Azizi, et al., 2019; Al-Harethi, et al., 2019; Mokhtar \& Bahari, 2017; and Hasbullah 2015; AbdulKareem, et al., 2019), the present study utilizes an extended version of the theory of planned behavior (TPB) (Ajzen, 1991; and Ajzen, 2005). Alongside the three original variables of TPB (attitude, subjective norms, and perceived behavioral control), this study also adds religiosity, knowledge, and trust to the awqaf institution as the extension. Primary data was collected from Indonesian respondents and analyzed using structural equation modeling (SEM).

The results of this study are expected to come up with several policies and practical implications. Determining the behavioral aspects of cash waqf would lead to insight into how the strategies and policies should be designed to optimize the cash waqf movement and implementation such as GNWU. This insight is not only beneficial for the regulator but also awqaf institution in Indonesia. The findings in this study are also expected to add literature in cash waqf in general and to provide insights and lessons for other countries.

The present paper is structured as follows. Section 2 discusses the research methods and data analysis. Section 4 presents the result and discussion. Section 5 is closed by conclusion and policy recommendations.

\section{METHOD}

The objective of this study is to investigate the factors influencing the intention of the public to endow cash waqf. The intention to endow cash waqf is investigated through a quantitative research method. According to Leedy \& Ormrod (2001), a quantitative approach is considered the most appropriate to meet the research objectives because such an approach is commonly used to establish, confirm or validate 
relationships, and develop generalizations that contribute to theory.

Given the result of the previous studies, which are based on conceptual and empirical studies explained earlier (particularly Shukor, et al., 2018; Osman \& Muhammad 2017; Hasbullah 2015; AbdulKareem, et al., 2019), the present study proposes the following empirical framework (see Figure 1). With the extended TPB approach, this study includes religiosity, knowledge, and trust variables as additional variables besides the common factors of TPB (attitude, subjective norms, and perceived behavior control) to strengthen the prediction of respondents' behavior and intention to endowing cash waqf.

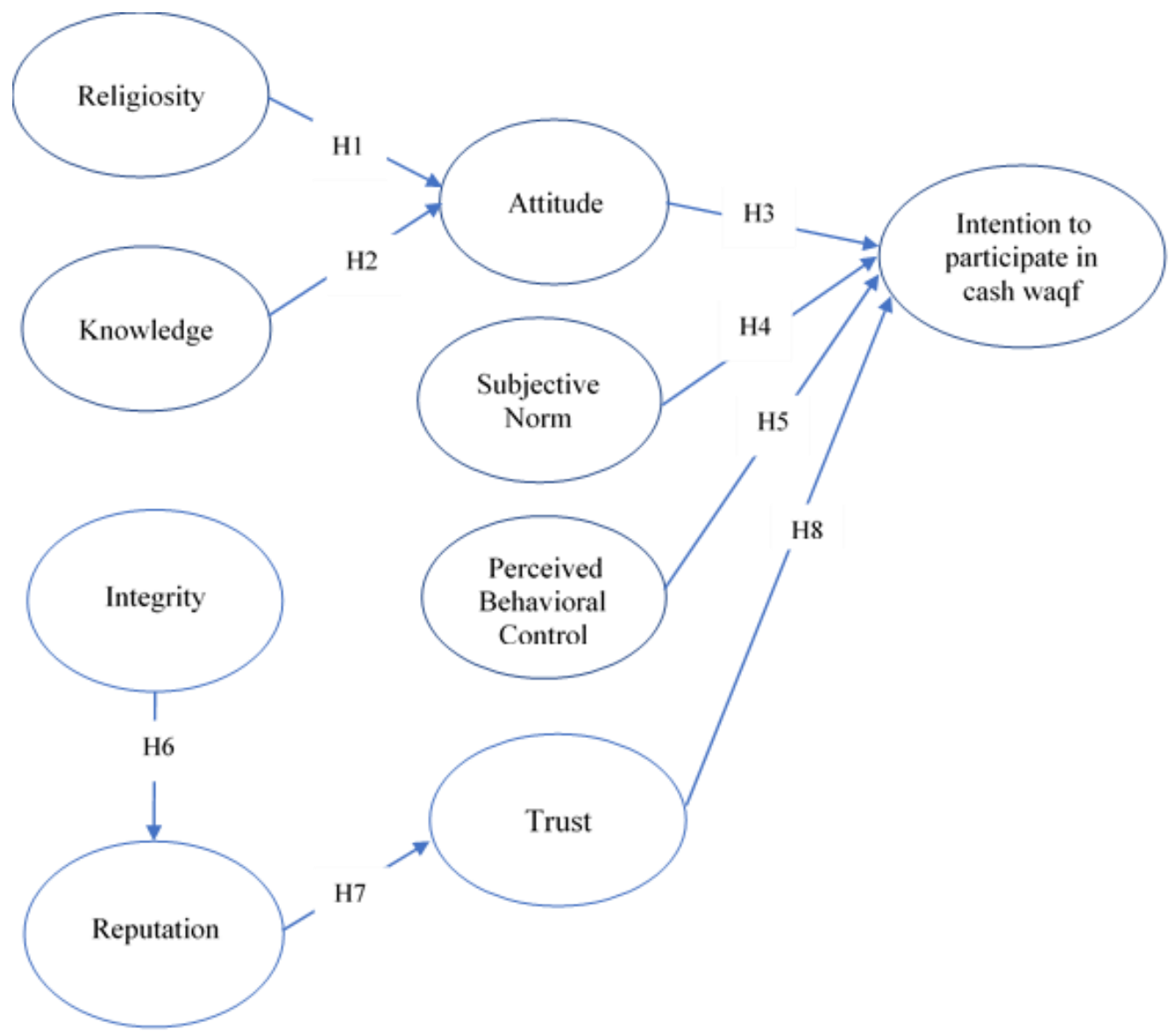

Figure 1. Empirical Framework of the Study

According to previous studies, these three variables of TPB (attitude, subjective norms and perceived behavioural control) are considered to have a significant influence on intention to endow cash waqf (Azizi, et al., 2019; AbdulKareem, et al., 2019; Osman, et al., 2016; Hasbullah, et al., 2015; Ratnasari \& Arifin, 2017; Zabri \& Muhammad, 2018; Osman \& Muhammed, 2017; Shukor, et al., 2017; and Yusoff, et al., 2017; Smith, et al., 2017) where almost all of the study conducted for Malaysia cases. Based on the abovementioned literature, it is believed that attitude, subjective norms and perceived behavioural control have a significant and positive influence on the intention to endow cash waqf.

Meanwhile, both perceived religiosity and knowledge are expected to have a positive relationship on attitude to cash waqf participation. Based on the previous studies (Rahman, et al., 2015; Iranmanesh, et al., 2019; Jana, et al., 2019; Vanany, et al., 2019; Amalia, et al., 2020; Osman, et al., 2016; Baqutayan \& 
Mahdzir, 2017; Mokhtar \& Bahari, 2017; and Johari, et al., 2015), it is generally believed that religiosity has a positive relationship with the intention to charitable donation including cash waqf endowment. Moreover, According to previous studies, knowledge has an influence on public (consumer) behaviour related to the implementation of Islamic economics (Aziz \& Chok, 2013; Hamdan, et al., 2013; Vanany, et al., 2019). The specific studies related to waqf such as Shukor, et al (2017) and Johari, et al (2015) show that knowledge influence decision making and behaviour of those who endow cash waqf (waqif). The study by Shukor, et al (2013) found that this variable is one of determinants to endow cash waqf, while the study by Johari, et al (2015) coined that the familiarity to cash waqf encourages people participation.

In addition, based on the scientific argument on the importance of trust in affecting charity program including cash waqf endowment and its correlation to integrity and reputation (Shukor, et al., 2018; Mustafa, et al., 2013; Bennett and Gabriel, 2003; Doney and Cannon, 1997; Ganesan, 1994; Einwiller, 2003; and Anderson \& Weitz, 1989) this study hypothesizes that Waqif's trust on awqaf institution has a positive influence on intention to endow cash waqf. This trust, while, is influenced by reputation and integrity of awqaf institution.

Based on this framework, a questionnaire is then constructed as the research instrument. The questionnaire consists of demographic characteristics and behaviors of the public concerning cash waqf, including attitude, subjective norms, perceived behavioral control, knowledge, religiosity, trust, integrity, reputation, and intention (see Table 1). The definition of cash waqf utilized in this study is that waqf paid and endowed by cash through all payment media. This definition is clearly explained in the introductory part of the questionnaire. Furthermore, in the behavioral section, the questions are mainly modified from Ajzen (2005), Shukor, et al (2018), Osman \& Muhammad (2017), Hasbullah (2015), AbdulKareem, et al (2019). The items were measured using a six-point Likert scale, from 'strongly disagree' (1) to 'strongly agree' (6). This even type of scale is used to prevent neutrality bias in answering the questions. A pilot study is conducted to assess the validity and reliability of the items included in the questionnaire. Based on its results, all variables in the model were acceptable as the Cronbach's alpha for all variables was above 0.7. Hence, all variables are reliable that none were removed from the model. The modification was only made for the wording aspect to make some aspect clearer suggested by the pilot tester.

In the next stage, primary data collection was conducted through the distribution of a self-administered questionnaire conducted in October-November 2020. A purposive sampling strategy is used with the questionnaire being distributed through several social media platforms. The sample used in this study is Muslim respondents with the demographic criteria depicted in Table 1. More than half $(58.25 \%)$ of them realized that they have participated in the waqf endowment in which $83.96 \%$ of this typical respondent have participated in cash waqf. The total sample analyzed in this study is 685 participants and this study utilizes 37 representative indicators. This number is more than sufficient based on the requirement set by Hair, et al (2006) and Zou \& Fu (2011). Hair et al. require at least five times the number of indicators, while Zou \& Fu (2011) only require a double of that size. Thus, 
the number of samples obtained in this study statistically meets the minimum target of sample size.

Table 1. Respondent's demographic characteristics

\begin{tabular}{|c|c|c|c|}
\hline Characteristics & Demographic Characteristics & $\begin{array}{c}\text { No. of } \\
\text { Respondents }\end{array}$ & Percentage(\%) \\
\hline \multirow{6}{*}{ Age Range } & $<18$ & 2 & 0.29 \\
\hline & $18-25$ & 121 & 17.66 \\
\hline & $26-35$ & 218 & 31.82 \\
\hline & $36-45$ & 186 & 27.15 \\
\hline & $46-55$ & 132 & 19.27 \\
\hline & $>55$ & 26 & 3.80 \\
\hline \multirow{2}{*}{ Gender } & Male & 427 & 62.34 \\
\hline & Female & 258 & 37.66 \\
\hline \multirow{3}{*}{ Marital Status } & Single & 184 & 26.86 \\
\hline & Widower & 6 & 0.88 \\
\hline & Married & 495 & 72.26 \\
\hline \multirow{6}{*}{ Latest Education Level } & Elementary School (SD/MI) & 3 & 0.44 \\
\hline & $\begin{array}{l}\text { Senior High School } \\
\text { (SMA/SMK/MA) }\end{array}$ & 100 & 14.60 \\
\hline & Junior High School (SMP/MTS) & 1 & 0.15 \\
\hline & Diploma ( $\left.\mathrm{D}_{1} / \mathrm{D}_{2} / \mathrm{D}_{3} / \mathrm{D}_{4}\right)$ & 26 & 3.80 \\
\hline & Bachelor Degree $\left(\mathrm{S}_{1}\right)$ & 355 & 51.82 \\
\hline & Post Graduate Degree $\left(\mathrm{S}_{2} / \mathrm{S}_{3}\right)$ & 200 & 29.20 \\
\hline $\begin{array}{l}\text { Have you ever attended religious } \\
\text { school (e.g. MI/MTS/MAN/Pesantren/ } \\
\text { or Higher education with a major in a } \\
\text { religious study such as Islamic }\end{array}$ & No & 305 & $44 \cdot 53$ \\
\hline $\begin{array}{l}\text { Economics, Islamic Business, Islamic } \\
\text { Accounting, Islamic Law, etc.) }\end{array}$ & Yes & 380 & $55 \cdot 47$ \\
\hline \multirow{10}{*}{ Occupation } & Student & 91 & 13.28 \\
\hline & Civil Servant & 204 & 29.78 \\
\hline & $\begin{array}{l}\text { The employee of state-owned } \\
\text { enterprise }\end{array}$ & 9 & 1.31 \\
\hline & TNI/Polri & o & 0.00 \\
\hline & The employee of private company & 161 & 23.50 \\
\hline & Entrepreneur & 81 & 11.82 \\
\hline & Housewife & 46 & 6.72 \\
\hline & Retired & 3 & 0.44 \\
\hline & Not Working & 10 & 1.46 \\
\hline & Other & 80 & 11.68 \\
\hline \multirow{5}{*}{ Monthly Income } & Less than Rp2.00o.0oo & 214 & 31.24 \\
\hline & Rp2.00o.0oo-Rp4.999.999 & 190 & 27.74 \\
\hline & Rp5.00o.ooo-Rp9.999.999 & 148 & 21.61 \\
\hline & Rp1o.ooo.ooo-Rp19.999.999 & 89 & 12.99 \\
\hline & Rp20.00o.ooo or more & 44 & 6.42 \\
\hline \multirow{2}{*}{ Are you an active social media user? } & No & 98 & 14.31 \\
\hline & Yes & 587 & 85.69 \\
\hline \multirow{3}{*}{$\begin{array}{l}\text { How often do you use social media in } \\
\text { one week (number of hours } \\
\text { accumulated)? }\end{array}$} & Rarely (1-3 jam) & 161 & 27.43 \\
\hline & Sometimes (3-10 jam) & 304 & 51.79 \\
\hline & Often (> 10 jam) & 122 & 20.78 \\
\hline
\end{tabular}




\begin{tabular}{|c|c|c|c|}
\hline Characteristics & Demographic Characteristics & $\begin{array}{c}\text { No. of } \\
\text { Respondents }\end{array}$ & Percentage(\%) \\
\hline \multirow{32}{*}{ Domicile (Province) } & Bali & 4 & 0.58 \\
\hline & Banten & 40 & 5.84 \\
\hline & Bengkulu & 2 & 0.29 \\
\hline & DKI Jakarta & 96 & 14.01 \\
\hline & Gorontalo & 8 & 1.17 \\
\hline & Jambi & 6 & 0.88 \\
\hline & West Java & 225 & 32.85 \\
\hline & Central Java & 53 & $7 \cdot 74$ \\
\hline & East Java & 59 & 8.61 \\
\hline & West Kalimantan & 6 & 0.88 \\
\hline & South Kalimantan & 5 & 0.73 \\
\hline & Central Kalimantan & 4 & 0,58 \\
\hline & East Kalimantan & 5 & 0.73 \\
\hline & North Kalimantan & 3 & 0.44 \\
\hline & Riau Islands & 5 & 0.73 \\
\hline & Lampung & 11 & 1.61 \\
\hline & Outside Indonesia & 1 & 0.15 \\
\hline & West Nusa Tenggara & 3 & 0.44 \\
\hline & East Nusa Tenggara & 5 & 0.73 \\
\hline & Papua & 2 & 0.29 \\
\hline & Riau & 12 & 1.75 \\
\hline & West Sulawesi & 10 & 1.46 \\
\hline & South Sulawesi & 15 & 2.19 \\
\hline & Central Sulawesi & 3 & 0.44 \\
\hline & Southeast Sulawesi & 2 & 0.29 \\
\hline & North Sulawesi & 3 & 0.44 \\
\hline & West Sumatera & 24 & $3 \cdot 50$ \\
\hline & South Sumatera & 19 & 2.77 \\
\hline & North Sumatera & 18 & 2.63 \\
\hline & Special Region of Yogyakarta & 20 & 2.92 \\
\hline & Bangka Belitung Islands & 6 & 0.88 \\
\hline & Nanggroe Aceh Darussalam & 10 & 1.46 \\
\hline
\end{tabular}

The primary data were subsequently analyzed using Structural Equation Modelling (SEM) with the support of LISREL 8.8 software. SEM is a statistical method that simultaneously expressing the relationship between several latent variables and tests dependency relationships (Hair, et al., 2014). It is antedated by confirmatory factor analysis to test the validity and reliability of the measurement model. Robustness and structural model tests are used to examine the relationships between the latent variables in the study. The goodness of the fit test is also performed. Notably, a research model is considered to have a good fit if there is at least one absolute fit index and one incremental fit index that meet the criteria (Hair, et al., 2014). Moreover, this study examines robustness by analyzing the covariance matrix for discriminant validity constructs. According to the Fornell-Larcker criterion, a proper construct is attained when an indicator's outer loadings on a certain construct are higher than all of its cross-loadings with the other constructs, and 
the square foot of each construct's Average Variance Extracted (AVE) is higher than its highest equivalence with any other constructs (Hair, et al., 2014). The results of the study are explained in the next section.

Before analyzing the structural model, several tests are conducted to assess the validity, reliability, and goodness of fit of the measurement model. There are no indicators or variables removed in this study. Table 2 depicts that all indicators have t-values of $\geq 1.645$ (one-tailed) and SLF of $\geq 0.5$, meaning those are valid. Also, all of the variables have $\mathrm{CR}$ of $\geq 0.6$ and AVE of $\geq 0.5$, meaning that those are reliable. Therefore, it can be suggested that all indicators used in this study are valid for explaining the variables. These items are also reliable or consistent in measuring the latent variables.

Table 2. Results of validity and reliability tests

\begin{tabular}{|c|c|c|c|c|c|}
\hline Latent Variable & Indicators & SLF & Error & CR Value & VE Value \\
\hline \multirow[t]{4}{*}{ Knowledge } & K1 & 0.86 & 0.27 & 0.86 & 0.85 \\
\hline & $\mathrm{K}_{2}$ & 0.89 & 0.21 & & \\
\hline & $\mathrm{K}_{3}$ & 0.78 & 0.40 & & \\
\hline & $\mathrm{K}_{4}$ & 0.74 & 0.46 & & \\
\hline \multirow[t]{6}{*}{ Attitude } & $\mathrm{A}_{1}$ & 0.69 & 0.52 & 0.73 & 0.73 \\
\hline & $\mathrm{A} 2$ & 0.75 & 0.44 & & \\
\hline & $\mathrm{A}_{3}$ & 0.78 & 0.39 & & \\
\hline & $\mathrm{A}_{4}$ & 0.67 & 0.56 & & \\
\hline & $\mathrm{A}_{5}$ & 0.79 & 0.38 & & \\
\hline & A6 & 0.76 & 0.42 & & \\
\hline \multirow[t]{5}{*}{ Subjective Norm } & SN1 & 0.73 & 0.46 & 0.80 & 0.77 \\
\hline & $\mathrm{SN}_{2}$ & 0.74 & 0.46 & & \\
\hline & $\mathrm{SN}_{3}$ & 0.61 & 0.62 & & \\
\hline & $\mathrm{SN}_{4}$ & 0.90 & 0.19 & & \\
\hline & $\mathrm{SN}_{5}$ & 0.88 & 0.22 & & \\
\hline Perceived Behavioural & $\mathrm{PBC}_{1}$ & 0.79 & 0.38 & 0.76 & 0.74 \\
\hline \multirow[t]{3}{*}{ Control } & $\mathrm{PBC}_{2}$ & 0.58 & 0.66 & & \\
\hline & $\mathrm{PBC}_{3}$ & 0.76 & 0.42 & & \\
\hline & $\mathrm{PBC}_{4}$ & 0.88 & 0.23 & & \\
\hline \multirow[t]{5}{*}{ Behavioural Intention } & BI1 & 0.88 & 0.23 & 0.91 & 0.90 \\
\hline & $\mathrm{BI} 2$ & 0.89 & 0.21 & & \\
\hline & $\mathrm{BI}_{3}$ & 0.85 & 0.28 & & \\
\hline & $\mathrm{BI}_{4}$ & 0.78 & 0.39 & & \\
\hline & $\mathrm{BI}_{5}$ & 0.86 & 0.27 & & \\
\hline \multirow[t]{3}{*}{ Integrity } & I1 & 0.80 & 0.35 & 0.91 & 0.91 \\
\hline & $\mathrm{I}_{2}$ & 0.89 & 0.20 & & \\
\hline & $\mathrm{I}_{3}$ & 0.87 & 0.24 & & \\
\hline \multirow[t]{3}{*}{ Reputation } & Re1 & 0.90 & 0.20 & 0.90 & 0.89 \\
\hline & $\operatorname{Re} 2$ & 0.82 & 0.33 & & \\
\hline & $\mathrm{Re}_{3}$ & 0.82 & 0.33 & & \\
\hline \multirow[t]{3}{*}{ Trust } & $\mathrm{T} 1$ & 0.89 & 0.21 & 0.97 & 0.97 \\
\hline & $\mathrm{T}_{2}$ & 0.94 & 0.12 & & \\
\hline & $\mathrm{T}_{3}$ & 0.94 & 0.12 & & \\
\hline \multirow[t]{4}{*}{ Religiosity } & R1 & 0.82 & 0.33 & 0.81 & 0.79 \\
\hline & $\mathrm{R}_{2}$ & 0.85 & 0.27 & & \\
\hline & $\mathrm{R}_{3}$ & 0.61 & 0.63 & & \\
\hline & $\mathrm{R}_{4}$ & 0.84 & 0.30 & & \\
\hline
\end{tabular}


After confirming the validity and reliability of the measurement model, the goodness-of-fit index (GOFI) calculation and the path analysis were conducted. Table III the measurement and structural models is a good fit. Therefore, it can be concluded that the proposed measurement and structural models appropriately represent the data. depicts the suggestion that the GOFI value of

Table 3. Results of goodness-of-fit test

\begin{tabular}{llcc}
\hline \multicolumn{1}{c}{ Measurements } & \multicolumn{1}{c}{ Criteria } & Result & Interpretation \\
\hline $\begin{array}{l}\text { Root Mean Square Error of } \\
\text { Approximation (RMSEA) }\end{array}$ & RMSEA $\leq 0.08$ & 0.073 & Good fit \\
$\begin{array}{l}\text { Tucker-Lewis Index or Non-Normed } \\
\text { Fit Index (TLI or NNFI) }\end{array}$ & TLI $\geq 0.9$ & & \\
Normed Fit Index (NFI) & NFI $\geq 0.9$ & & Good fit \\
Relative Fit Index (RFI) & RFI $\geq 0.9$ & 0.97 & Good fit \\
Incremental Fit Index (IFI) & IFI $\geq 0.9$ & 0.96 & Good fit \\
Comparative Fit Index (CFI) & CFI $\geq 0.9$ & 0.97 & Good fit \\
Parsimonious Goodness of fit (PGFI) & PGFI $>0.60$ & 0.97 & Good fit \\
\hline
\end{tabular}

RMSEA = Root mean square error of approximation, NFI $=$ Normed fit index, NNFI $=$ Non-normed fit index, CFI $=$ Comparative fit index, IFI = Incremental fit index, and RFI = Relative fit index

\section{RESULTS AND DISCUSSION}

In testing the hypotheses, the structural equation model was estimated using the maximum likelihood method after all of the measurement and structural models were confirmed. The result explained the relationships between the latent variables (See figure 2).

Overall, the results of the study confirmed the hypotheses tested. Thus, the intention to endow cash waqf in Indonesia is significantly and positively influenced by all of the TPB variables (attitude, subjective norm, perceived behavioral control) and the variable of trust in awqaf institutions. Religiosity and knowledge were also significant in explaining the intended behavior of cash waqf through attitude. Meanwhile, integrity and reputation significantly influenced intention behavior to endow cash waqf through the trust variable.
Interestingly, a little difference was found in this study for the trust variable where the mentioned variable is usually directly influenced by both integrity and reputation (see Shukor et al., 2018). The present study demonstrated that integrity was firstly mediated by the reputation variable. These results implied that a more positive attitude, better supporting environment, good access and facilities to participate in cash waqf and a higher degree of trust in awqaf institution positively influence the intention of people to endow cash-waqf in Indonesia. To encourage the public attitude, the knowledge of cash waqf could be increased, making this attitude statistically better for those who have a good degree of religiosity. Meanwhile, to build public trust on awqaf institutions, the organization should create good integrity and reputation. 


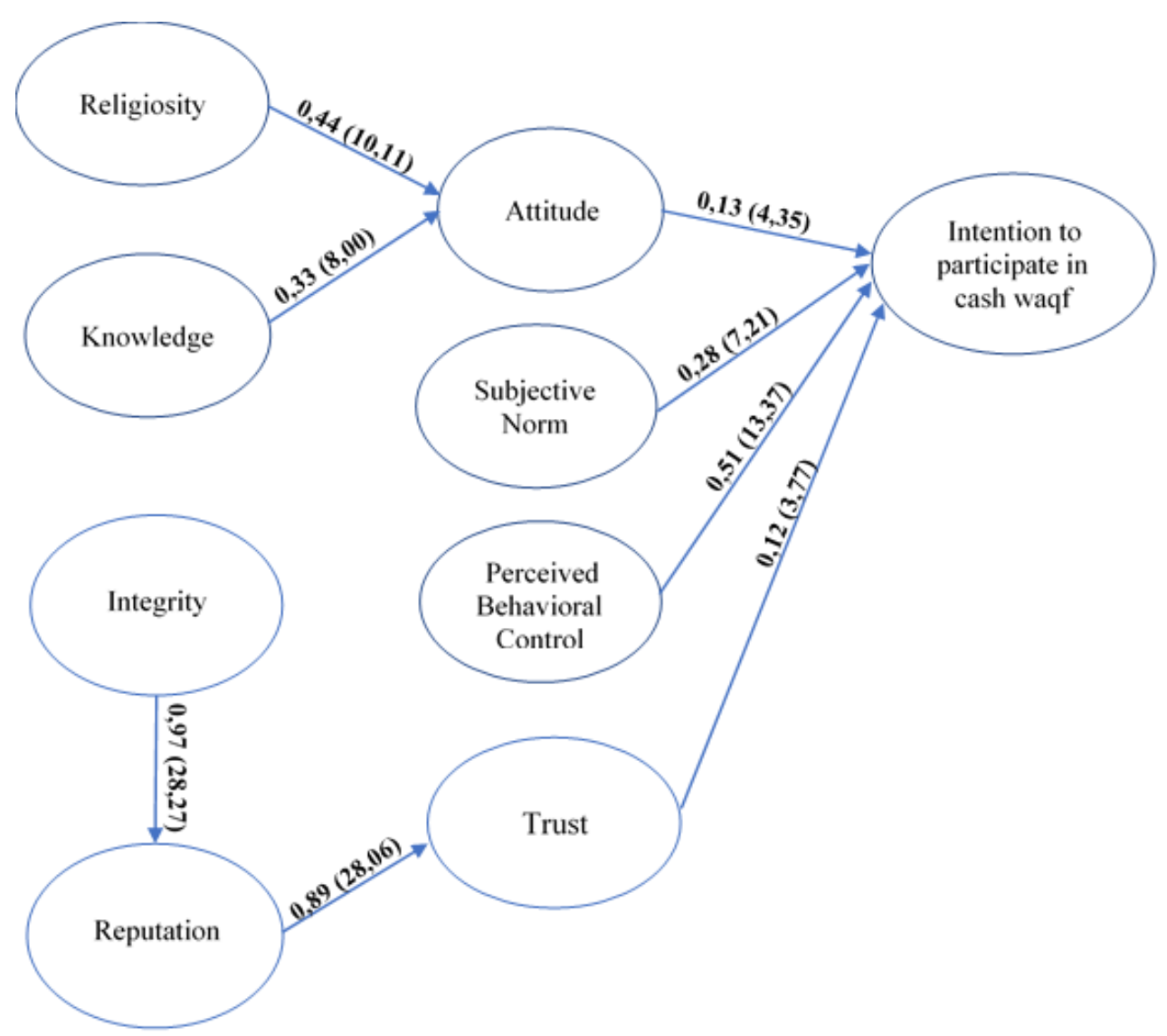

Figure 2. Summary of the SEM results

Table 4 shows the strength of these relationships. The coefficient determinations suggested that the intention variable could be explained by TPB variables and trust in awqaf institutions at $68 \%$. Besides, religiosity and knowledge could explain attitude to a degree of $38 \%$. Meanwhile, the trust could be explained by reputation at a degree of $79 \%$ in which the last variable was almost perfectly explained by integrity (the coefficient determination was $94 \%$ ).

Table 4. Coefficient of Determination

\begin{tabular}{lcc}
\hline \multicolumn{1}{c}{ Structural Model } & Error Variant & $\begin{array}{c}\text { Coefficient of } \\
\text { Determination }\end{array}$ \\
\hline $\mathrm{BI}=0.13^{*} \mathrm{~A}+0.28^{*} \mathrm{SN}+0.12^{*} \mathrm{~T}+0.51^{*} \mathrm{PBC}$ & 0.32 & 0.68 \\
$\mathrm{~A}=0.33^{*} \mathrm{~K}+0.44^{*} \mathrm{R}$, & 0.62 & 0.38 \\
$\mathrm{Rep}=0.97^{*} \mathrm{I}$ & 0.06 & 0.94 \\
$\mathrm{~T}=0.89^{*} \mathrm{Rep}$ & 0.21 & 0.79 \\
\hline
\end{tabular}

As expected in the hypotheses, these results confirm that TPB variables are good determinants of behavior to endow cash waqf. This finding is consistent with the previous studies (Osman \& Muhammed, 2017; Yusoff, et al., 2017; Hasbullah, et al., 2015; AbdulKareem, et al., 2019; and Azizi, 2019). First, a positive attitude towards cash waqf is crucial in creating people's intention towards cash waqf endowment. The positive attitude is represented by the good perception, the belief regarding the religious reward, and the positive impact of waqf on both society and development. This study also finds the similar result to the study by Osman, et al (2016), Baqutayan \& Mahdzir (2017), Indahsari, et al 
(2014), and Fuadah, et al (2015), demonstrating that one of the variables influencing the intention to endow cash waqf, by encouraging the positive attitude towards cash waqf, is religiosity. The rationale for this lies in religious teaching which advocates people to participate in cash waqf. The principles are instilled through various campaigns and education. This result also implies that participating in charitable donations, including cash waqf, is a sign of a Muslim individual's commitment to the religion (Johnson, et al., 2001). This commitment, then, will create the attitude and construct the behavior needed for the endowment of cash waqf. Moreover, another variable relevant in encouraging a positive attitude is knowledge. Based on the result of this study, more knowledgeable respondents appear to have more positive attitudes regarding giving cash waqf than those who are less knowledgeable. This result is not surprising, given that knowledge regarding cash waqf must be possessed before deciding whether or not to participate. This finding is also in line with the conclusions of Shukor, et al (2017), and, et al (2015).

Secondly, people's intention towards cash waqf endowment is also supported by the surroundings. People tend to have intention in giving cash waqf if they feel that their environment and their surroundings also have the same feeling. This study confirms that subjective norms are significant in encouraging people to participate in cash waqf. This result somewhat indicates that the intention of Indonesian Muslims to endow cash waqf is presumably affected by 'external' factors such as social pressure. If they feel that their families, close relatives, and significant others are happy and supportive of their participation in waqf, their intention towards cash waqf endowment will increase.
Third, the intention also depends on the people's capability and accessibility to cash waqf participation. This aspect is normally measured by factors such as financial ability, freedom to act, and facility (or access). The result of this study suggests that better facilities and access to cash waqf will therefore increase the intention to endow cash waqf, thus, facilitating the variation of cash waqf program, media, and easiness to endow cash waqf, leading to higher intention towards cash waqf endowment.

Other than the aspect deriving from TPB variables, this study also reveals that the intention to endow cash waqf is also significantly influenced by the trust on awqaf institutions. This finding is consistent with that of a previous study by Shukor, et al (2018) and Osman, et al (2016). As expected, the result of this study suggests that increasing the trust towards awqaf institutions will lead the public to endow the cash waqf. This aspect is more crucial in the context of cash waqf since the behavior of cash waqf could be categorized as voluntary action, commonly supporting the non-profit organization or public institution. Seong Gin (2017) pointed that public trust for this type of organization is problematic since this factor will also affect credibility and legitimacy.

Furthermore, findings from this study also suggest that the trust on awqaf institutions depends on the integrity and reputation of this institution. Hence, to encourage public participation in cash waqf, the awqaf institution should practice the organization's integrity and maintain a good reputation. This finding is also in line with that of Shukor, et al (2018). However, this study finds that the integrity of awqaf institutions does not directly influence public trust. Rather than that, integrity indirectly influences trust through reputation. It indicates that increasing the organization's integrity will increase the reputation of the 
awqaf institution which subsequently builds waqif's trust in the institution.

\section{CONCLUSION}

Despite the potential and government agenda towards cash waqf, this area has been given limited attention in the academic literature especially in the aspect of supply side. This study, thus, attempts to scrutinize the public behaviour in this niche area and coming out with strategy and policy recommendation. However, more variables could also be added in the model. Focus on several types of community and background is also interesting to be explored. Further research, therefore, could elaborate on these aspects.

Based on the findings that have been explained, this study comes up with several recommendations which could be classified into optimizing waqf fund collection and waqf fund management sides. There is two recommendation for both sides. The first recommendation to optimize the cash waqf collection in Indonesia is improving the public literacy and campaign regarding cash waqf. Through literacy improvement, the public attitude will become more positive towards cash waqf. Besides, literacy also encourages public attitude through knowledge transfer which is a determinant of positive attitude. To literate the public on cash waqf, the related institution could implement several strategies which probably could be effective such as collaboration with the ulama and community engagement since this study also finds that both subjective norms and religiosity are significant factors in influencing the intention towards cash waqf. Besides that, the campaign on cash waqf is also possible in adapting to behavioral change techniques. This technique, contemporarily, is believed to be effective in public persuasion especially for the program related to charitable donation like cash-waqf.

The second recommendation to optimize cash waqf collection is improving the quality and quantity of facilities and supporting systems to participate in cash waqf endowment. Improving those two aspects will automatically create good accessibility for the public to endow cash waqf. One of the approaches which can be adopted is system digitalization. Since public digital literacy is now in massive growth, this adoption will significantly increase the accessibility and easiness to participate in cash waqf. Apart from that, the media to participate in cash waqf could be combined with the daily public activities system such as bank transfer, emoney system, and payment system in a retail store.

Furthermore, the recommendation of this study for the aspect of the management side is strengthening the institutional management of cash waqf. This recommendation is important in making sure that people feel safe and satisfy with the cash waqf they endow. Good management of waqf is the key to people's trust. Good integrity is represented by good management covering waqf asset management and benefit distribution. This integrity will lead to a good reputation which automatically creates trust. Maintaining people's trust is not only beneficial to engage new waqif but also to encourage current waqif to re-donate.

Another point that should be highlighted for both the waqf collection side and waqf fund management side is that they both should be improved simultaneously. The optimization of cash waqf depends on these two sides so that one of them cannot be ignored or left out. A good collection will support sustainable management and vice versa. Thus, the relationship between these two sides is like supply and demand; creating an optimal equilibrium from both sides is crucial to gain the most beneficial and impactful benefits from cash waqf for both the economy and the society. 


\section{REFERENCES}

Ab Rahman, A, (2009). The role of waqf in the economic development of Muslims and its application in Malaysia [Peranan wakaf dalam pembangunan ekonomi umat Islam dan aplikasinya di Malaysia]. Jurnal Shariah, 17, 113-152.

AbdulKareem, I. A., Ogunbado, A. F., AbdulGaniyy, A., \& Mahmud, M. S, (2019). Factors Motivating the Establishment of Waqf Institution towards Poverty Alleviation among Muslim Ummah in Oyo State, South West, Nigeria. Jurnal Manajemen Bisnis, 32(1), 41-59.

Ajzen, I. (1991). The theory of planned behavior. Organizational Behavior and Human Decision Processes, 5o(2), 179-211.

Ajzen, I. (2005). Attitudes, Personality, and Behaviour and ed. New York: McGraw Hill.

Al-Harethi, A. R. S. (2019). Factors Determine Cash Waqf Participation in Kedah, Malaysia: Perception from Students in Kolej University Insaniah. Ikonomika, 4(1), 53-59.

Amalia, F. A., Sosianika, A. \& Suhartanto, D, (2020). Indonesian Millennials' Halal food purchasing: merely a habit?. British Food Journal, 122(4), 1185-1198.

Aziz, A., \& Chok, N. V. (2013). The role of Halal awareness, Halal certification, and marketing components in determining Halal purchase intention among non-Muslims in Malaysia: a structural equation modeling approach. Journal of International Food and Agribusiness Marketing 25(1), 1-23.

Azizi, N. D., Shukor, S. A., \& Sabri, H. (2019). Determinants Of Repeated
Endowers'donation Intention In Cash Waqf: A Case Study In Majlis Agama Islam Dan Adat Melayu Perak (MAIPk). Jurnal Manajemen Bisnis, 10(2), 154-163.

Baqutayan, S. M., \& Mahdzir, A. M. (2017). The psychology theories of waqf-giving behaviors. Journal of Economic and Social Thought, 4(4), 424-432.

Benjamin, M. (1990). Splitting the Difference: compromise and Integrity in Ethics and Politics. Kansas: University Press of Kansas.

Bennett, R., \& Ali-Choudhury, R. (2009). Second-gift behaviour of first-time donors to charity: an empirical study. International Journal of Nonprofit and Voluntary Sector Marketing, 14(3) 161180.

Bennett, R., \& Gabriel, H. (2003). Image and reputational characteristics of UK charitable organizations: an empirical study. Corporate Reputation Review, 6(3), 276-289.

Burnett, K, (1992). Relationship Fundraising. London: White Lion Press.

Cizakca, M. (200o). A History of Philanthropic Foundations: The Islamic World From the Seventh Century to the Present. Istanbul: Bogazici University Press.

Doney, P. M., \& Cannon, J. P. (1997). An examination of the nature of trust in buyer-seller relationships. The Journal of Marketing, 61(2), 35-51.

Einwiller, S. (2003). When reputation engenders trust: an empirical investigation in business-to-Consumer Electronic commerce. Electronic Markets, 13(3), 196-209.

Ganesan, S. (1994). Determinants of long-term orientation in buyer-seller relationships. Journal of Marketing 58(2), 1-19.

Hair, J. F., Black, W. C., Babin, B. J., Anderson, R.E., \& Tatham, R. L. (2006). Multivariate data analysis (Vol. 6). New 
Jersey: Pearson Prentice Hall, Upper Saddle River.

Hamdan, H., Issa, Z. M., Abu, N. \& Jusoff, K., (2013). Purchasing decisions among Muslim Consumers of processed halal food products. Journal of Food Products Marketing, 19(1), 54-61.

Hasbullah, N. A., Khairi, K. F., \& Aziz, M. R. A. (2016). Intention to contribute in corporate waqf: Applying the Theory of Planned Behaviour. UMRANInternational Journal of Islamic and Civilizational Studies 3(1).

Indahsari, K., Burhan, M. U., Ashar, K., \& Multifiah. (2014). Determinants of individual Muslim behaviour in accomplishing zakah, infaq, shadaqah and waqf through amil institution. International Journal of Economic Policy in Emerging Economies 7(4), 346-365.

Iranmanesh, M., Mirzaei, M., Hosseini, S. M. P., \& Zailani, S. (2019). Muslims' willingness to pay for certified halal food: an extension of the theory of planned behaviour. Journal of Islamic Marketing, 11(1), 14-30.

Jana, D., Sinha, A. \& Gupta, A. (2019), Determinants of Financial Literacy and Use of Financial Services: An Empirical Study Amongst the Unorganized Sector Workers in Indian Scenario. Iranian Journal of Management Studies, 12(4), 657-675.

Johari, F., Alias, M. H., Shukor, S. A., Abd Wahab, K., Aziz, M. R. A., Ahmad, N., \& Ibrahim, P. (2015). Factors That Influence Repeat Contributionof Cash Waqfin Islamic Philanthropy. Management \& Accounting Review (MAR), 14(2), 55-78.

Johnson, B. R., Jang, S. J., Larson, D. B., \& De Li, S. (2001). Does adolescent religious commitment matter? Are examination of the effects of religiosity on delinquency. Journal of Research in Crime and Delinquency, 38(1), 22-44.

Kahf, M. (1999). Financing the development of awqaf property. The American Journal of Islamic Social Sciences, 16(4), 39-66.

Kashif, M., Sarifuddin, S., \& Hassan, A. (2015). Charity donation: intentions and behaviour. Marketing Intelligence and Planning, 33(1), 90-102.

Kuran, T. (2001). The provision of public goods under Islamic law: Origins, impact, and limitations of the waqf system. Law and Society Review, 35(4), 841-898.

Leedy, P., \& Ormrod, J. (2001). Practical research: Planning and design (7th ed.). New Jersey: Merrill Prentice Hall.

Mahamood, S. M. (2006). Waqf in Malaysia: Legal and Administrative Perspective. Kuala Lumpur: Penerbit Universiti Malaya.

Mohamed Yusof, M. F., Hasarudin, M. H. \& Romlin, N. (2017). Cash waqf and infaq: a proposed ephilanthropy in Malaysia. Jurnal Kemanusiaan, 22, 1-10.

Mustafa, M. O. A., Muslim, H. S. M., \& Adnan, M. A. (2013). Antecedents of zakat payers' trust in an emerging zakat sector: an exploratory study. Journal of Islamic Accounting and Business Research, 4(1), 4-25.

Ong, F. S., \& Moschis, G. P. (2006), Religiosity and consumer behavior: a crosscultural study. International Conference on Business and Information, 3, 1-13.

Osman, A. F., Mohammed, M. O., \& Fadzil, A., (2016). Factor influencing cash Waqf giving behavior: A revised theory of planned behavior. Journal of Global Business and Social Entrepreneurship, $1(2), 12-25$.

Osman, A. F., \& Muhammed, M. O. (2017). Measuring a Cash Waqf Giving Behavior among Muslim Donors in Malaysia: A Theory of Planned Behavior Approach 
Using Structural Equation Modeling. The Journal of Muamalat and Islamic Finance Research, 204(5775), 1-25.

Rahman, A. A., Asrarhaghighi, E., \& Rahman, A. S. (2015). Consumers and Halal cosmetic products: knowledge, religiosity, attitude and Intention. Journal of Islamic Marketing, 6(1), 148-163.

Ratnasari, R. T., \& Arifin, M. H. (2017). Theory of planned behavior in intention to pay cash waqf.

Sadeq, A. M. (2002), Waqf, perpetual charity and poverty alleviation. International Journal of Social Economics 29(1/2), 135-151.

Said, N. M., \& Saad, R. A. J. (2016). Determinants of hibah giving behavior. The European proceedings of social $\mathcal{E}$ behavioural sciences (EpSBS), 437-442.

Seong-Gin, M., 2017. "The effect of trust in giving: evidence from KoreanAmericans in California”. The Korean Journal of Policy Studies 32(1): 53-70.

Shukor, S. A., Johari, F., Abd Wahab, K., Kefeli, Z., Ahmad, N., Alias, M. H., \& Abu-Hussin, M. F. (2018). Trust on awqaf institutions: evidence from Malaysia. Journal of Islamic Marketing, 10(2), 511-524.

Shukor, S. A., Anwar, I. F., Sabri, H., Abd Aziz, S., \& Ariffin, A. R. M. (2017). Giving Behaviour: Who Donates Cash Waqf. Malaysian Journal of Consumer and Family Economics, 87-100.

Smith, J. R., \& McSweeney, A. (2007). Charitable giving: the effectiveness of a revised theory of planned behaviour model in predicting donating intentions and behaviour. Journal of Community and Applied Social Psychology, 17(5), 363-386.
Vanany, I., Soon, J. M., Maryani, A., \& Wibawa, B. M. (2019). Determinants of halal-food consumption in Indonesia. Journal of Islamic Marketing, 11(2), 507-521.

Wahbah, Z. (1985). Al-Fiqh al-Islamiy wa 'adillatuhu'. MesirL Dar al-Fikr alMu'ashir.

Yusoff, R., Abd Rahman, S. A., \& Wan, W. N. (2017). Predicting the Behavioural Intention for Cash Waqf: Evidence from Malaysia and Thailand.

Zabri, M. Z. M., \& Mohammed, M. O. (2018). Examining the behavioral intention to participate in a Cash Waqf-Financial Cooperative-Musharakah Mutanaqisah home financing model. Managerial Finance, 44(6), 809-829.

Zain, N. H. M., Muda, M., \& Rosman, R. (2019). Personality Factors Influencing Intention on Cash Waqf Behavior. International Journal of Business, Economics and Law, 18(2), 23-30.

Zou, S., \& Fu, H. (2011). International Marketing and Emerging Markets: An Introduction to the AIM Volume 21, in Zou, S. and Fu, H. (Ed.) International Marketing (Advances in International Marketing, Vol. 21), Bingley: Emerald Publishing. 


\section{APPENDIX}

Appendix 1. Variable and items of the questionnaire

\begin{tabular}{|c|c|c|c|}
\hline Variable & Code & Indicator & Source \\
\hline \multirow[t]{7}{*}{ Attitude } & A1 & I have a good perception of cash waqf & \multirow{7}{*}{$\begin{array}{l}\text { Osman and } \\
\text { Muhammad 2017; } \\
\text { Shukor et al., 2018; } \\
\text { Hasbullah 2015; } \\
\text { AbdulKareem et al., } \\
2019\end{array}$} \\
\hline & A2 & I believe that participating in a cash waqf & \\
\hline & \multirow{2}{*}{ A3 } & I believe that by giving cash waqf I will receive & \\
\hline & & benefits either in this world or hereafter & \\
\hline & $\mathrm{A}_{4}$ & $\begin{array}{l}\text { I believe that participating in cash waqf program } \\
\text { is also counted as alms }\end{array}$ & \\
\hline & $\mathrm{A}_{5}$ & $\begin{array}{l}\text { I believe that participating in cash waqf program } \\
\text { can increase the socio-economic development of } \\
\text { society }\end{array}$ & \\
\hline & A6 & $\begin{array}{l}\text { I am happy to be able to contribute to the cash } \\
\text { waqf program }\end{array}$ & \\
\hline \multirow[t]{5}{*}{$\begin{array}{l}\text { Subjective } \\
\text { Norm }\end{array}$} & $\mathrm{SN} 1$ & $\begin{array}{l}\text { Many people around me are supporting me to } \\
\text { participate in the cash waqf program }\end{array}$ & \multirow[t]{5}{*}{$\begin{array}{l}\text { Osman and } \\
\text { Muhammad } 2017\end{array}$} \\
\hline & $\mathrm{SN}_{2}$ & $\begin{array}{l}\text { People who are close to me think that I should } \\
\text { take part in the cash waqf program }\end{array}$ & \\
\hline & $\mathrm{SN}_{3}$ & $\begin{array}{l}\text { When I take part in cash waqf program, people } \\
\text { who are important to me would consider it as a } \\
\text { noble act }\end{array}$ & \\
\hline & $\mathrm{SN}_{4}$ & $\begin{array}{l}\text { My family are supporting me to participate in } \\
\text { the cash waqf program }\end{array}$ & \\
\hline & $\mathrm{SN}_{5}$ & $\begin{array}{l}\text { My family are very happy when I can take part in } \\
\text { the cash waqf program }\end{array}$ & \\
\hline \multirow{5}{*}{$\begin{array}{c}\text { Perceived } \\
\text { Behavioral } \\
\text { Control }\end{array}$} & \multirow[t]{2}{*}{$\mathrm{PBC}_{1}$} & I have enough income to be able to contribute to & \multirow{5}{*}{$\begin{array}{l}\text { Osman and } \\
\text { Muhammad 2017; } \\
\text { Hasbullah 2015; } \\
\text { AbdulKareem et al., } \\
2019\end{array}$} \\
\hline & & the cash waqf program & \\
\hline & $\mathrm{PBC}_{2}$ & $\begin{array}{l}\text { The decision to contribute to the cash waqf } \\
\text { program is entirely on me }\end{array}$ & \\
\hline & $\mathrm{PBC}_{3}$ & $\begin{array}{l}\text { If I want, I can contribute to the cash waqf } \\
\text { program anytime }\end{array}$ & \\
\hline & $\mathrm{PBC}_{4}$ & I can participate in the cash waqf program & \\
\hline \multirow[t]{4}{*}{ Knowledge } & K1 & $\begin{array}{l}\text { I am familiar with the concept and programs of } \\
\text { waqf }\end{array}$ & \multirow[t]{4}{*}{ Shukor et al., 2018.} \\
\hline & $\mathrm{K}_{2}$ & I think I know a lot about waqf & \\
\hline & $\mathrm{K}_{3}$ & $\begin{array}{l}\text { I have enough knowledge about waqf } \\
\text { institutions and Indonesia Waqf Bodies (BWI) }\end{array}$ & \\
\hline & $\mathrm{K}_{4}$ & $\begin{array}{l}\text { I have participated or often participate in the } \\
\text { waqf program }\end{array}$ & \\
\hline \multirow[t]{2}{*}{ Intention } & I1 & $\begin{array}{l}\text { I have the desire to participate in the cash waqf } \\
\text { program shortly }\end{array}$ & $\begin{array}{l}\text { Osman and } \\
\text { Muhammad 2017; }\end{array}$ \\
\hline & I2 & $\begin{array}{l}\text { There is the possibility that I will participate in } \\
\text { the cash waqf program soon }\end{array}$ & $\begin{array}{l}\text { Hasbullah 2015; } \\
\text { AbdulKareem et al., }\end{array}$ \\
\hline
\end{tabular}




\begin{tabular}{|c|c|c|c|}
\hline Variable & Code & Indicator & Source \\
\hline & $\mathrm{I}_{3}$ & $\begin{array}{l}\text { I will choose the cash waqf program as an } \\
\text { alternative to donate }\end{array}$ & $\begin{array}{l}\text { 2019; Shukor et al., } \\
2018 .\end{array}$ \\
\hline & $\mathrm{I}_{4}$ & $\begin{array}{l}\text { I will recommend the cash waqf program for my } \\
\text { friends and people around me }\end{array}$ & \\
\hline & $\mathrm{I}_{5}$ & $\begin{array}{l}\text { My desire to participate in the cash waqf } \\
\text { program is getting stronger day by day }\end{array}$ & \\
\hline \multirow[t]{4}{*}{ Religiosity } & $\mathrm{R} 1$ & Religion is very important for me & PEW Research \\
\hline & $\mathrm{R}_{2}$ & $\begin{array}{l}\text { I always try to follow the orders and avoid } \\
\text { restrictions of my religion }\end{array}$ & \\
\hline & $\mathrm{R}_{3}$ & I always participate in every religious service & \\
\hline & $\mathrm{R}_{4}$ & $\begin{array}{l}\text { A strong sense of God's presence in my every } \\
\text { activity is very important for me }\end{array}$ & \\
\hline \multirow[t]{3}{*}{ Trust } & T1 & $\begin{array}{l}\text { I believe that waqf institutions have tried their } \\
\text { best on helping people to do waqf }\end{array}$ & Shukor et al., 2018 \\
\hline & $\mathrm{T} 2$ & I think I have trust in waqf institutions & \\
\hline & $\mathrm{T}_{3}$ & $\begin{array}{l}\text { I think the managing process conducted by waqf } \\
\text { institutions can be trusted. }\end{array}$ & \\
\hline \multirow[t]{3}{*}{ Integrity } & Int1 & $\begin{array}{l}\text { In my opinion, the work program created by } \\
\text { waqf institutions can be fulfilled }\end{array}$ & Shukor et al., 2018 \\
\hline & Int2 & $\begin{array}{l}\text { In my opinion, waqf constitutions have shown } \\
\text { consistency between what they say and what } \\
\text { they do }\end{array}$ & \\
\hline & Int3 & $\begin{array}{l}\text { In my opinion, waqf institutions have a high } \\
\text { value of honesty }\end{array}$ & \\
\hline \multirow[t]{3}{*}{ Reputation } & Rep1 & $\begin{array}{l}\text { In my opinion, the process of collecting and } \\
\text { managing cash waqf has a positive reputation }\end{array}$ & Shukor et al., 2018 \\
\hline & Rep2 & $\begin{array}{l}\text { In my opinion, the collection and management } \\
\text { of cash waqf have been transparent both in } \\
\text { terms of finance and policy }\end{array}$ & \\
\hline & Rep3 & $\begin{array}{l}\text { In my opinion, the collection and management } \\
\text { of cash waqf have been considered well by the } \\
\text { community }\end{array}$ & \\
\hline
\end{tabular}

